\title{
CORTADERIA (GRAMINEAE): INTERSPECIFIC HYBRIDS AND THE BREEDING SYSTEMS
}

\author{
H. E. CONNOR* \\ Botany Division, Department of Scientific and Industrial Research, \\ Christchurch. New Zealand
}

Received 1.iii.83

\begin{abstract}
SUMMARY
Interspecific hybrids between New Zealand decaploid species of Cortaderia (Section Bifida) are fertile and share a common gene(s) for control of male sterility, the determinant of their gynodioecious breeding system. The interspecific hybrid between the two sexually reproducing species of Section Cortaderia is $F_{1}$ fertile, but shows some slight degeneration in later generations especially through lethal albinism. They share a common gene(s) for male sterility control.

Experimental intersectional hybrids are nonoploid and sterile. $F_{1}$ C. araucana $\times$ C. toetoe consisted of a family of solely female plants with the androecial morphology of the female parent. Such hybrids share the two main characteristics of the several apomictic taxa in Section Cortaderia; intersection hybridisation is a possible pathway towards the evolution of solely female taxa. $F_{1} C$. toetoe $\times C$. selloana segregated plants of both sex-forms. Different male sterility genes, or alleles, occur in the two Sections, and ratios of hermaphrodite to female plants are intersectionally discrete.
\end{abstract}

\section{INTRODUCTION}

The grass Cortaderia, a genus of about 25 species, includes hermaphroditism, gynodioecism, near dioecism, autonomous apomixis in monomorphic female populations, self-incompatibility, and self-compatibility in its repertoire of breeding systems (Connor, 1965a, b, 1974, 1979, 1981; Philipson, 1978; Costas-Lippman, 1979). Hermaphroditism occurs exclusively in $C$. sericantha; gynodioecism, where separate female and hermaphrodite plants occur in populations, is found in Sections Cortaderia, Bifida and Monoaristata; near dioecism occurs in C. selloana, Section Cortaderia; self-incompatility in $C$. selloana; self-compatibility in C. fulvida, $C$. richardii, $C$. splendens, and $C$. toetoe; precocious autonomous (nonpseudogamous) apomixis in C. atacamensis, $C$. jubata, $C$. rudiuscula and $C$. speciosa of Section Cortaderia, and $C$. bifida is the only known apomict in Section Bifida. All autonomously apomictic taxa consist of plants with the sexual characteristics found only in female plants, and occur on the South American Continent.

Indigenous New Zealand species, Section Bifida, are decaploid $2 n=$ $10 x=90$; the New Guinean taxon C. archboldii is octoploid; and tetra-, octo- and dodecaploid taxa occur among South American species (Connor and Edgar, 1974).

Two topics of significant interest are the origin of autonomous somatic apospory, and the genetics of male sterility in gynodioecous species. Both will be discussed here.

* Present address: Centre for Resource Management, University of Canterbury, Private Bag, Christchurch, New Zealand. 
As part of a variety of studies, interspecific hybrids have been made experimentally; these provide the basic information for this paper. All hybrids are fertile except the nonoploids; one intersectional hybrid produced a family of solely female plants.

\section{Material AND METHODS}

Isolated inflorescences of female plants were hand pollinated and yielded the following hybrids; female parents are listed first, pollen is from hermaphrodite plants; no attempts were made to intercross hermaphrodites by hand:

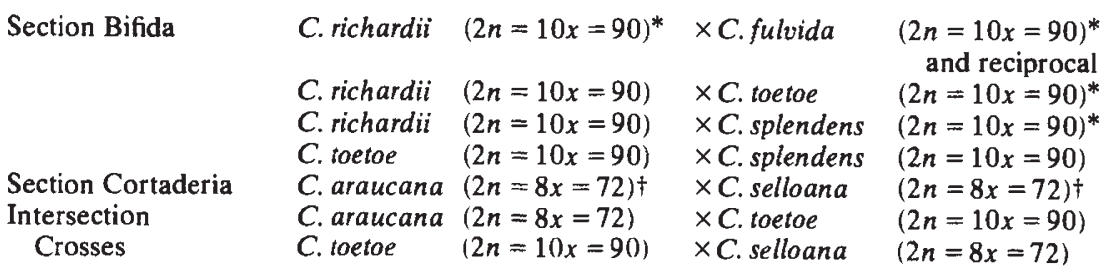

All plants were raised in the uniform environment of the Botany Division experimental garden at Lincoln, Canterbury. Nomenclature follows Connor and Edgar (1974).

Sex forms of all plants were checked at least twice; neither chimeras nor sex reversals were found.

Differences in time of flowering of the species are significant. To overcome the three month difference in flowering time between $C$. richardii and $C$. toetoe, florally induced plants of $C$. richardii were kept cool and shaded until about one month before the flowering of $C$. toetoe; they were then brought into ambient conditions. This treatment delayed, in particular, the elongation of culm internodes and thus inflorescence emergence.

Pollen of $C$. richardii was collected 12-14 December 1977, stored at $-13^{\circ} \mathrm{C}$ in a mixture with 50 per cent polyvinylpyrrilidone, and used successfully with $C$. splendens females on 12 January 1978 .

The very occasional out of season flowering in some species provided useful material for attempting hybridisation.

\section{REsults}

$F_{1}$ hybrids were easily produced even where there were different levels of ploidy, as for example in decaploid C. toetoe pollinated with octoploid C. selloana. Intrasectional hybrids are all vigorous, and are morphologically intermediate between the parents though early flowering tends to dominate over late flowering. Intersectional hybrids are vigorous too, despite a few stunted plants, and show that the diagnostic single nerve in the lamina of species in Section Cortaderia is dominant over the three-nerved state in New Zealand species of Section Bifida. The lemma in Section Bifida is characterised by two long, awn-like lobes lateral to the awn; this character

\footnotetext{
* New Zealand endemics.

$\dagger$ southern South American endemics.
} 
dominates the lobeless, or very shortly lobed, lemmata of Section Cortaderia.

We have shown elsewhere that $F_{1}$ hybrids combine the triterpene methyl ether complements of the parent species (Connor and Purdie, 1976), and that there is segregation in $F_{2}$ and backcross generations for synthesis of these compounds.

Sex-form frequencies among several generations of hybrids are in table 1 ; results from intraspecific crosses, not presented here, are substantially the same as those and support the interpretations offered below. The segregation ratios, especially the $3 \mathrm{MF}: 1 \mathrm{MS}$ ratios, indicate that male sterility is not under the control of a dominant gene.

\section{(i) Hybrids in Section Bifida}

The fertility of $F_{1}$ 's among the decaploid New Zealand species was sufficiently high to ensure the easy production of $\mathrm{F}_{2}$ from selfing of hermaphrodites, or from intercrossing $F_{1}$ females and hermaphrodites. Backcrossing was successful. No barriers to gene exchange or to the production of subsequent generations from selfing were found.

Hermaphrodites of all New Zealand species are strongly self-compatible. Fertility in one hybrid was estimated from seed-set and pollen stainability; percentage seed-set in selfed hermaphrodites of $\mathrm{F}_{1} C$. richardii $\times$ C. fulvida in four plants was $71 \cdot 0,71 \cdot 2,82 \cdot 2,83 \cdot 8$; pollen fertility was on average 96.2 per cent; seed -set on backcrossing $F_{1}$ female plant by $C$. fulvida pollen was 89.3 per cent and $\mathrm{F}_{1} \times C$. richardii was 88.1 per cent.

Segregation for sex-form in several generations of four interspecific hybrids are included in taole 1 , and show that fits to simple ratios can be obtained, but departures are frequent. I have already shown that a fit to such simple ratios inadequately explains the control of male sterility in $C$. richardii (Connor, 1974) and, by analogy, that of the three other New Zealand endemics.

\section{(ii) Hybrids in Section Cortaderia}

Because there are only two sexual species in Section Cortaderia the only hybrid made is $C$. araucana $\times C$. selloana; both parents are octoploid. The $F_{1}$ was readily produced, and from seeds from selfing hermaphrodites, and from interpollination of females with hermaphrodites, $F_{2}$ generations were raised. $F_{2}$ fertility was reduced relative to $F_{1}$; and what seemed to be self-incompatibility in $F_{2}$ hermaphrodites affected the size of $F_{3}$ families.

Backcrosses of $F_{1}$ females with pollen of the two parents were produced with ease. In one backcross family there was significant albinism among the seedlings (c. 30 per cent) much as there was in one family from the selfing of an $F_{1}$ hermaphrodite plant, but not as extensive as in a family from the selfing of an $F_{2}$ hermaphrodite plant (see table 1). Gene exchange could be restricted in later generations by hybrid inviability expressed as a relatively high level of lethal albinism in seedlings.

Segregation for sex-form in three generations is presented in table 1; fits to simple genetic ratios were obtained, but these easy fits are an inadequate guide to the solution of the intractable problem of the genetics of male sterility in C. selloana at least (Connor, 1974, 1981). 


\section{TABLE 1}

Sex-form frequencies in hybrid generations in Cortaderia; female parent listed first; number of families in generations in parenthesis

\begin{tabular}{|c|c|c|c|}
\hline & $\Varangle$ & $q$ & $1: 1$ or $3: 1$ \\
\hline \multicolumn{4}{|l|}{ Section Bifida } \\
\hline \multicolumn{4}{|l|}{ C. richardii $\times C$. fulvida (and reciprocal) } \\
\hline$F_{1}(3)$ & 75 & 65 & $1: 1=0.71$ \\
\hline $\mathrm{F}_{2}$ from selfing $(7)$ & 270 & 67 & $3: 1=4 \cdot 71^{*}$ \\
\hline $\mathrm{F}_{2}$ from interpollination $q \times \delta^{\pi}(2)$ & 47 & 47 & $1: 1=0$ \\
\hline $\mathrm{F}_{1} \times$ fulvida & 34 & 16 & $1: 1=6.48^{*}$ \\
\hline $\mathrm{F}_{1} \delta \times$ richardii 9 (1) & 31 & 19 & $1: 1=2 \cdot 88$ \\
\hline \multicolumn{4}{|l|}{ C. richardii $\times C$. toetoe } \\
\hline$F_{2}$ from selfing (4) & 704 & 210 & $3: 1=1.99$ \\
\hline $\mathrm{F}_{2}$ from interpollination $\$ \times \delta(2)$ & 286 & 212 & $1: 1=10 \cdot 99 * * *$ \\
\hline $\mathrm{F}_{1} \times$ richardii $(1)$ & 117 & 94 & $1: 1=2 \cdot 51$ \\
\hline $\mathrm{F}_{1} \times$ toetoe $(2)$ & 256 & 242 & $1: 1=0.39$ \\
\hline \multicolumn{4}{|l|}{ C. richardii $\times$ C. splendens } \\
\hline$F_{1}(1)$ & 91 & 101 & $1: 1=0.52$ \\
\hline $\mathrm{F}_{2}$ from selfing (1) & 182 & 62 & $3: 1=0.22$ \\
\hline $\mathrm{F}_{2}$ from interpollination $q \times \delta(1)$ & 148 & 97 & $1: 1=10 \cdot 62 * *$ \\
\hline \multicolumn{4}{|l|}{$C$. splendens $\times C$. toetoe } \\
\hline$F_{1}(3)$ & 341 & 347 & $1: 1=0.05$ \\
\hline \multicolumn{4}{|l|}{ Section Cortaderia } \\
\hline \multicolumn{4}{|l|}{ C. araucana $\times$ C. selloana } \\
\hline$F_{1}(1)$ & 129 & 127 & $1: 1=0.02$ \\
\hline$F_{2}$ from selfing $(2)$ & 386 & $119+$ & $3: 1=0.56$ \\
\hline $\mathrm{F}_{2}$ from interpollination $q \times \delta(2)$ & 247 & 251 & $1: 1=0.03$ \\
\hline $\mathrm{F}_{3}$ from selfing $(5)$ & 120 & $48 \ddagger$ & $3: 1=1 \cdot 43$ \\
\hline $\mathrm{F}_{1} \delta \times$ araucana $\stackrel{(2)}{ }$ & 273 & $217 \S$ & $1: 1=6 \cdot 43^{*}$ \\
\hline$F_{1} \times$ selloana $(4)$ & 485 & 494 & $1: 1=0.08$ \\
\hline \multicolumn{4}{|l|}{ Intersection Hybrids } \\
\hline \multicolumn{4}{|l|}{ C. toetoe $\times$ C. selloana } \\
\hline$F_{1}(1)$ & 27 & 36 & $1: 1=1 \cdot 28$ \\
\hline \multicolumn{4}{|l|}{ C. araucana $\times$ C. toetoe } \\
\hline$F_{1}(1)$ & 0 & 157 & (99 did not flower) \\
\hline
\end{tabular}

$\uparrow 24$ per cent albino seedlings in one family.

\$ about 50 per cent albino seedlings in one family.

$\$ 29$ per cent albino seedling in one family.

\section{(iii) Intersectional hybrids}

Cortaderia araucana $(2 n=8 x=72) \times$ C. toetoe $(2 n=10 x=90)$ and $C$. toetoe $\times C$. selloana $(2 n=72=8 x=72)$ were easily-made hybrids; $C$. araucana pollinated by $C$. splendens set abundant seed, but the vigorous $\mathrm{F}_{1}$ has so far not reached flowering.

$\mathrm{F}_{1}$ C. araucana $\times$ C. toetoe $(2 n=9 x=81)$ was made in $1971 ; 28$ plants came to flower for the first time in 1973 and by 1981 there were 157 plants that had flowered in a family of 256; all plants that have flowered are female. One plant was a $C$. araucana maternal female. This totally female family is perhaps a special case of diplontic sterility i.e. it is impossible for the hybrids to generate hermaphrodite flowers. It is, after 10 years, unlikely to be an example of retarded flowering of hermaphrodite plants! The 
individual hermaphrodite $C$. toetoe plant used as pollen parent is heterogametic because it segregated both hermaphrodite and female plants in a family from selfing, and was pollen parent in a hybrid with $C$. splendens that yielded families with plants of both sex-forms. No genetic influence attributable to $C$. toetoe alone can explain the absence of hermaphrodite plants in $\mathrm{F}_{1} C$. araucana $\times C$. toetoe.

The intersectional hybrid $C$. toetoe $\times C$. selloana differs in two important ways from the cross with $C$. araucana; both sex-forms were present, and the reduced androecium in female plants differs in size and in organisation. In $F_{1}$ in its first year (1981) 37 plants came to flower in November, two months ahead of the earlier parent's flowering time-C. toetoe flowers in late January-and four months before the later flowering C. selloana. In 1982 flowering was also under way by November. Of the plants that have so far flowered, 27 are pollen sterile hermaphrodites and 36 are females; there are 7 other plants small in stature and apparently genetically inharmonious.

\section{(iv) The Androecium}

Genes controlling androecium development in female flowers of species in Section Cortaderia differ from those in species of Section Bifida. In Section Cortaderia the genetic system affects anthers and filaments at an early stage of their ontogeny (see Connor, $1974 \mathrm{fig} .1$ ), but in species of Section Bifida male sterility is delayed in its expression until the formation of microspores is completed in anthers that are, until then, normal in their development. In evolutionary terms, male sterility genes in species of Section Cortaderia are more advanced than those in Section Bifida because their effect is an immediate one, and one that is economical in terms of energy and metabolite conservation in female plants.

The androecium in female flowers of $C$. araucana and $C$. selloana is reduced to a set of staminodes each with a small, but clearly defined anther region; in female flowers of $C$. toetoe bilobed, pollenless anthers are borne on long filaments. The $\mathrm{F}_{1} C$. toetoe $\times C$. selloana and $C$. araucana $\times C$. toetoe are not intermediate between the parents for anther length in female flowers; anther length is dominated by genes from $C$. araucana and $C$. selloana (table 2). In the $C$. araucana $\times C$. toetoe hybrid a stamen in a female flower consists of a small pandurate anther region on a short thick filament, just as in $C$. araucana itself. In the hybrid $C$. toetoe $\times C$. selloana the stamen of a female flower consists of a bilobed anther about $0.5 \mathrm{~mm}$ long on a filament $1 \cdot 2-1 \cdot 4 \mathrm{~mm}$ long; this condition combines the filament of typical anthers in $C$. toetoe female flowers with a somewhat longer bilobed anther than is typical of $C$. selloana female flowers. Anthers of this exact state are found only in female flowers of $C$. pilosa among the twenty species for which I have data (see table 1 in Connor, 1974).

The only other floral character deserving mention is the heterotic effect measurable in stigma-style length in hermaphrodite flowers of all hybrids except $C$. araucana $\times C$. selloana (table 2 ). This, on the surface, is not a phenomenon of great significance, but it does indicate that stigma-style length, which is controlled seemingly simultaneously with male sterility, is open to other genetic influence. Anther length in hermaphrodite flowers is not significantly affected. 
TABLE 2

Anther and stigma-style length $(\mathrm{mm})$ in parental species and interspecific hybrids in Cortaderia: some data from table 1 in Connor (1974)

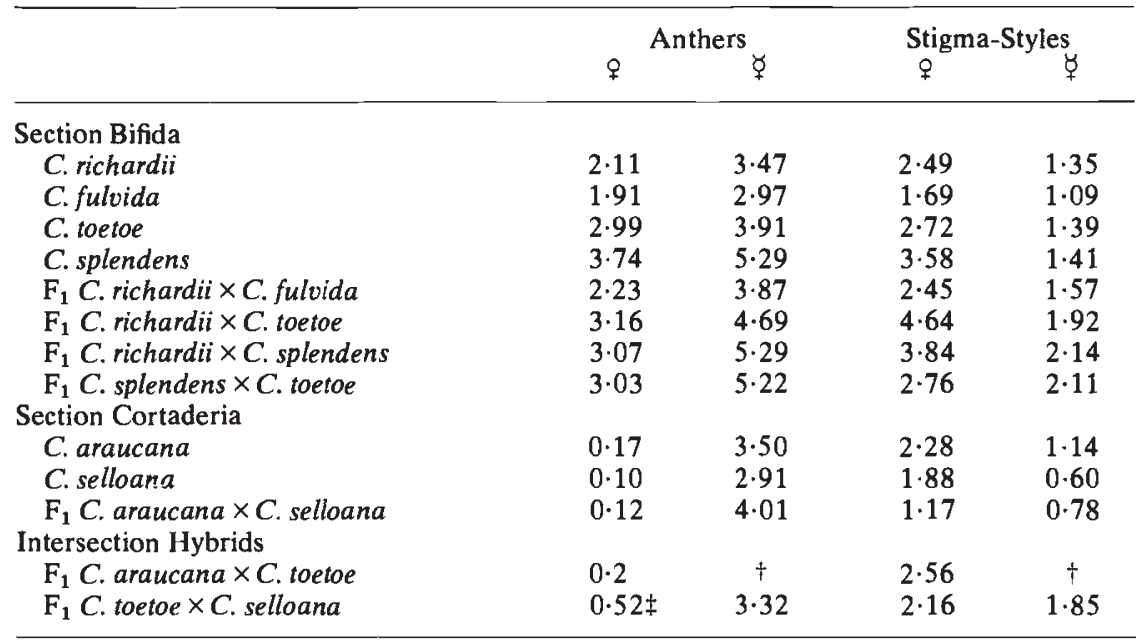

$\dagger$ No hermaphrodites in family.

$\ddagger$ On filaments $1 \cdot 2-1 \cdot 4 \mathrm{~mm}$ long.

\section{Discussion}

(i) Hybrid viability

The first point to emerge from this study is that interspecific $F_{1}$ hybrids are very easily made. Among the New Zealand endemic decaploid species there are no evident physiological barriers to gene exchange; all four species are clearly quite closely related. Geographic distribution limits the opportunities for some of these species to cross, and differences in time of flowering are an extra constraint.

Two sexual South American octoploids, C. araucana and C. selloana, cross easily, and seed is freely set; time of flowering is very different in the experimental garden. Although $F_{1}$ seed-set in selfed hermaphrodites was abundant, there were numerous albino seedlings in $\mathrm{F}_{2}$; albinos also occurred among $F_{3}$ seedlings and in the backcross of $F_{1}$ female to $C$. araucana. Some restriction in hybrid viability occurs between these species, but it may not seriously limit gene exchange. Hermaphrodites of $F_{1}$ seemed quite selffertile even though hermaphrodites of $C$. selloana set only the very smallest amount of seed on self-pollination, and I classify the taxon as self-incompatible; $F_{2}$ plants when selfed seemed not as self-compatible as $F_{1}$ but still more so than $C$. selloana itself.

\section{(ii) Male sterility genes}

The second point of interest is that the gene(s) controlling male sterility are identical in the New Zealand species; this is measured by (i) common segregations for sex-form in $F_{1}, F_{2}$, and backcross generations (table 2), (ii) common morphogenesis of male sterility as seen in anther development and size, (table 1), (iii) common lemma vestiture in both sex forms. The 
gene(s) in octoploid $C$. selloana and C. araucana are probably identical too, but they are not the same as those in New Zealand decaploids. The difference between these two sets of genes is seen particularly in their action in androecium development in the intersectional hybrids C. araucana $\times$ C. toetoe and C. toetoe $\times$ C. selloana (table 2). In neither of these hybrids is the developmental pathway to male sterility expressed as in the New Zealand endemics although 45 chromosomes are contributed by $C$. toetoe and 36 by $C$. selloana and $C$. araucana. These data indicate different male sterility genes, or at least different alleles, in the two sections of the genus.

Both sets of hybrids share 3:1 ratios for sex-form segregation, an indication that male sterility is not controlled by a dominant gene in either Section. Hermaphrodites are heterogametic in species in both Sections.

From the experimental crosses nothing can be directly interpreted to suggest cytoplasmic control of male sterility, nor, even making allowance for different chromosomal balances, are the genetic systems sufficiently imbalanced to prevent the production of both sex-forms except in $F_{1}$ $C$. araucana $\times C$. toetoe where the male fertility system of $C$. toetoe is inoperative and $F_{1}$ is feminised.

\section{(iii) Segregation ratio}

Another indication of distinct male sterility genetic systems between species in Section Cortaderia and Section Bifida is revealed by the simple hermaphrodite:female segregation ratios in $C$. araucana $\times C$. selloana families as compared with the complex ratios in families of hybrids in the New Zealand endemics (table 1). The only departure from expectation in C. araucana $\times$ C. selloana lay in a backcross family where albino seedlings were frequent.

Among the various generations of interspecific hybrids in Section Bifida, significant departures from expectations based on male sterility control by a single gene occur among four families. Although I have elsewhere (Connor, 1974) presented sufficient data to indicate that the simple one gene solution I offered some years ago (Connor, 1965b) was inadequate, the attempts here to fit simple ratios, even in the presence of some significant heterogeneity, are intended to emphasise the difference between Section Bifida and Section Cortaderia.

(iv) Origin of apomictic species

The two intersectional hybrids reveal information useful when considering the evolution of sex-form expression and of apomixis in the genus. That the interspecific hybrid $C$. toetoe $\times C$. selloana has stamens of the form found only in female flowers of tetraploid C. pilosa, the sole species in Section Monoaristata, is of interest. C. pilosa is the only species where female fiowers have very reduced bilobed anthers on filaments that carry them to the level of the tip of the gynoecium. Contemporary differences aside, one pathway to the formation of stamens of that morphology can be indicated.

In Cortaderia all the apomictic species are found in Section Cortaderia except for $C$. bifida; that $C$. bifida reproduces asexually is confirmed by 
its recent behaviour in our experimental gardens. Apomictic, monomorphic species of Section Cortaderia are characterised by very small staminodes in female flowers, and the absence of the hermaphrodite or male sex-form. The artificial hybrid $C$. araucana $\times C$. toetoe produced female plants only, and these have the sex-form morphology of species in Section Cortaderia. It is conceivable that high polyploid apomictic species of Section Cortaderia could have arisen this way and had members of Section Bifida in their backgrounds; there, the characteristic androecium of Section Cortaderia would dominate the Section Bifida form, and the feminising influence seen in one of my experiments could be expressed. Such a pathway would possess the characters commonly associated with the origin of apomixis, i.e. hybridism, and high levels of polyploidy. Of course, the intervention of a major embryological alteration is needed to allow autonomous somatic apospory to be generated in such hybrids. Two steps are probably involved, the first to ensure regular degeneration of the normal megagametophyte and its substitution by nucellar aposporous embryo sacs. In the second a completely nonpseudogamous syndrome must be achieved. These same embryological interventions would be needed, however, to allow the direct evolution of autonomous agamospermy in females of a gynodioecious (or dioecious) taxon. This latter is the more readily accepted hypothesis for the origin of taxa such a $C$. jubata, $C$. rudiuscula and $C$. speciosa (Connor, 1981), but need not be the sole one.

$\mathrm{F}_{1}$ family $C$. araucana $q \times C$. toetoe ${ }^{\star}$ consists of female monomorphic plants with $2 n=9 x=81$; they are sterile, setting no seed after controlled pollination, open-pollination, or in isolation. Purely female families may result from crosses involving cytoplasmic male sterility (see review of Edwardson, 1970), but the one result reported here does not allow a cytoplasmic interpretation because $C$. araucana, the mother plant, responded differently to the two males used. Nor is there any evidence from sex-form segregation (table 1 and unpublished) for cytoplasmic control of male sterility, and both Lloyd and I have shown genic control of sex ratios in C. richardii and C. selloana (Connor, 1974; Lloyd, 1976).

Cytoplasmic control of gynodioecism has been discussed recently by Charlesworth and Ganders (1979), by Charlesworth (1981), and by Delannay, Gouyon and Valdeyron (1981), but their proposals are scarcely implicated here, even though their models contain characteristics and pathways that parallel, quite readily but not necessarily appropriately, results that are found here.

Families of purely female plants have been reported before in interspecific hybrids e.g., in Bryonia and Amaranthus (see summary in Westergaard, 1958); in both these genera totally female families arose from crosses between females of dioecious species and pollen from male flowers of monoecious species. And it is probably worthwhile reminding ourselves that Gustafsson (1946-47) drew attention once again to the relationship that may exist between apomixis and dioecism, as for example in Antennaria (Stebbins, 1932), and Wikstroemia (Fagerlind, 1940).

The species of Cortaderia in South America and New Zealand have evolved along distinctive paths and towards different levels of polyploidy$4 x, 8 x, 12 x$ in South America, and $10 x$ in New Zealand. At the least, in addition to the distinctive gynodioecious breeding system retained by species in both countries, and the generation of different genes for male 
sterility and of some correlated floral characters, the ability to intercross persists in the face of the long isolation since the breakup of Gondwanaland.

Acknowledgments. I am grateful to Mr A. W. Purdie, Botany Division, for technical assistance over several years, and to Drs D. Charlesworth, E. J. Godley, D. G. Lloyd, and C. J. Webb for discussion and for reading the text. Mr I. W. Brown, Botany Division, was responsible for raising and caring for the 7000 plants described here.

\section{REFERENCES}

CHARLESWORTH, D. 1981. A further study of the problem of the maintenance of females in gynodioecious species. Heredity, 46, 27-39.

CHARLESWORTH, D. AND GANDERS, F. R. 1979. The population genetics of gynodioecy with cytoplasmic-genic male-sterility. Heredity, 43, 213-218.

CONNOR, H. E. $1965 a$. Breeding systems in New Zealand grasses. V. Naturalized species of Cortaderia. N.Z. J. Botany, 3, 17-23.

CONNOR, H. E. $1965 b$. Breeding systems in New Zealand grasses. VI. Control of gynodioecism in Cortaderia richardii (Endl.) Zotov. N.Z. J. Botany, 3, 233-242.

CONNOR, H. E. 1974. Breeding Systems of Cortaderia (Gramineae). Evolution, 27, 663-678. CONNOR, H. E. 1979. Breeding Systems in the grasses: a survey. N.Z. J. Botany, 17, 547-574. CONNOR, H. E. 1981. Evolution of reproductive systems in the Gramineae. Ann. Miss. Bot. Gard., 68, 48-78.

CONNOR, H. E. AND EDGAR, E. 1974. Names and types in Cortaderia Stapf (Gramineae). Taxon, 23, 596-605.

CONNOR, H. E. AND PURDIE, A. w. 1976. Inheritance of triterpene methyl ethers in Cortaderia (Gramineae). Phytochemistry, 15, 1937-1939.

COSTAS-LIPPMANN, M. 1979. Embryogeny of Cortaderia selloana and C. jubata (Gramineae). Bot. Gaz., 140, 393-397.

DELANNAY, X., GOUYON, P. H. AND VALDEYRON, G. 1981. Mathematical study of the evolution of gynodioecy with cytoplasmic inheritance under the effect of a nuclear restorer gene. Genetics, 99, 169-181.

EDWARDSON, J. R. 1970. Cytoplasmic male sterility. Bot. Rev., 36, 341-420.

FAGERLIND, F. 1940. Zytologie und Gametophytenbildung in der Gattung Wikstroemeria. Hereditas, 26, 23-50.

GUSTAFSSON, A. 1946-47. Apomixis in Higher Plants. Gleerup, Lund.

LLOYD, D. G. 1976. The transmission of genes via pollen and ovules in gynodioecious Angiosperms. Theoretical Population Biol., 9, 299-316.

PHILIPSON, M. N. 1978. Apomixis in Cortaderia jubata (Gramineae). N.Z. J. Botany, 16, 45-59.

Stebbins, G. L. 1932. Cytology of Antennaria. II. Parthenogenetic Species. Bot. Gaz., 44, 322-344.

WESTERGAARD, M. 1958. The mechanism of sex determination in dioecious flowering plants. Adv. Gen., 9, 217-281. 